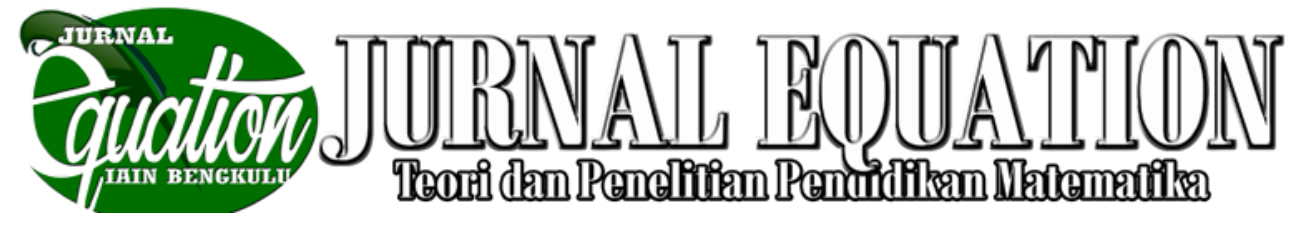

Volume 2 Nomor 1, Maret 2019, ISSN 2599-3291 (Cetak), ISSN 2614-3933 (Online)

\title{
Penggunaan Math Game Kartu Remi Berhitung (Karetung) Terhadap Kemampuan Operasi Hitung Siswa
}

\author{
Annisa Bunga Pertiwi 1), Dwi Novia Ningrum²), \\ Tadris Matematika IAIN Curup \\ annisaeffendi3@gmail.com
}

\begin{abstract}
ABSTRAK
Jenis penelitian yang digunakan dalam penelitian ini yaitu quasi eksperimen. desain penelitian yang digunakan yaitu one group pretest-postest design. populasi dari penelitian ini adalah siswa kelas V SDN 8 Rejang Lebong. Teknik pengambilan sampel pada penelitian ini adalah sampling jenuh. Uji coba instrument yang digunakan adalah uji validitas dan uji reliabilitas. Analisa data menggunakan uji prasyarat yaitu uji normalitas dan uji homogenitas dan uji hipotesis menggunakan uji t. Dalam pelaksanaan pembelajaran menggunakan Kartu Remi Berhitung (Karetung) pada operasi hitung terdapat pengaruh yang signifikan antara penggunaan Karetung terhadap kemampuan berhitung siswa SDN 8 Kabupaten Rejang Lebong dengan nilai thit $=48,66$ dan thitung $\geq$ ttabel yaitu 48,66 $\geq 1,68$ sehingga $\mathrm{H} 0$ ditolak yang artinya $\mathrm{H} 1$ diterima. Adapun hasil observasi pada pertemuan I menunjukkan bahwa siswa masih kurang memperhatikan penjelasan guru tentang materi, siswa masih melakukan kecurangan pada permainan math games seperti mencabut kartu sebanyak dua kali, masih salah berhitung dalam bermain yaitu disebabkan karena masih kurangnya kemampuan siswa dalam berhitung sehingga menyebabkannya kesulitan dalam menurunkan kartu remi saat gilirannya memberikan kartu dan membutuhkan waktu yang cukup lama dalam bermain (lembar observasi terlampir). Adapun hasil observasi pada pertemuan II telah menunjukkan hasil yang lebih baik daripada pertemuan I dimana siswa lebih cepat bermain karena telah terbiasa dengan operasi hitung yang diberikan.
\end{abstract}

Kata Kunci : Math Game, Kartu Remi Berhitung, Kemampuan Berhitung 


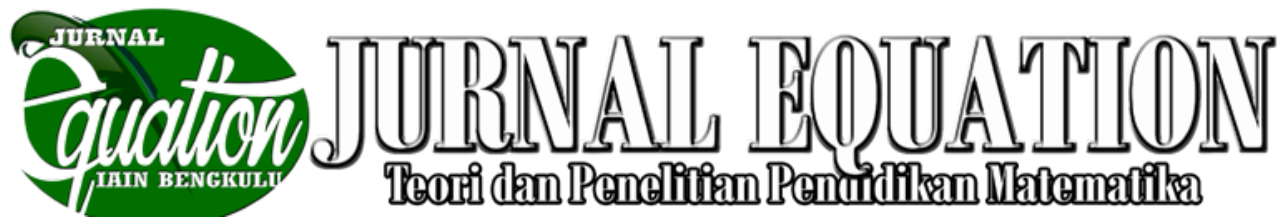

Volume 2 Nomor 1, Maret 2019, ISSN 2599-3291 (Cetak), ISSN 2614-3933 (Online)

\section{PENDAHULUAN}

Pendidikan menurut UU No 20 Tahun 2003 menyatakan bahwa pendidikan adalah usaha sadar dan terencana untuk mewujudkan suasana belajar dan proses pembelajaran agar peserta didik secara aktif mengembangkan potensi dirinya untuk memiliki kekuatan spiritual keagamaan, pengendalian diri, kepribadian, kecerdasan, akhlak mulia, serta keterampilan yang dipelukan dirinya, masyarakat, bangsa, dan negara. Sejalan dengan tantangan dunia di era modern ini, pendidikan merupakan salah satu hal yang sangat penting dalam sendi kehidupan, karena pendidikan adalah salah satu penentu nasib dan kemajuan bangsa serta penentu kemampuan sumber daya manusianya dalam suatu negara. Kemajuan suatu bangsa tidak hanya dilihat dari kekayaan sumber alamnya saja tetapi juga dapat dilihat dari kemampuan sumber daya manusianya sendiri.

Pembelajaran merupakan salah satu bagian dari pendidikan yang melibatkan guru sebagai sumber daya manusia, karena guru itu sendiri sangat menentukan kualitas pendidikan. Apalagi di era saat ini, banyak siswa-siswi yang kurang mencintai pendidikan sehingga menjadi tugas besar guru untuk dapat melakukan proses pembelajaran yang menyenangkan agar siswa mencintai apa yang ia pelajari di dalam pendidikan. Hal ini sesuai dengan konsep pembelajaran yang menyatakan bahwa pembelajaran merupakan proses komunikasi dua arah, mengajar dilakukan oleh pihak guru sebagai pendidik, sedangkan belajar dilakukan oleh peserta didik atau murid (Sagala, 2011:61). Dalam pembelajaran di sekolah, siswa menerima banyak mata pelajaran baik tentang ilmu pengetahuan alam, ilmu pengetahuan sosial, pendidikan kewarganegaraan, bahasa Indonesia, bahasa Inggris, maupun matematika. Namun, di antara sekian banyaknya mata pelajaran tersebut, matematika merupakan salah satu mata pelajaran yang sangat tidak dicintai oleh siswa-siswi. Banyak faktor yang mempengaruhinya di antaranya faktor dari dalam diri siswa maupun dari luar diri siswa. Kebanyakan siswa-siswi di sekolah jenuh dengan pelajaran matematika karena disebabkan belum adanya suatu hal yang baru yang mampu membangkitkan minat belajar siswa terhadap mata pelajaran matematika seperti permainan matematika, metode belajar yang menarik, penggunaan tutor sebaya, dan lain-lain yang jarang sekali digunakan dalam proses pembelajaran.

Dalam kegiatan belajar di SDN 8 Rejang Lebong, keaktifan siswa dalam kegiatan belajar mengajar masih kurang, 


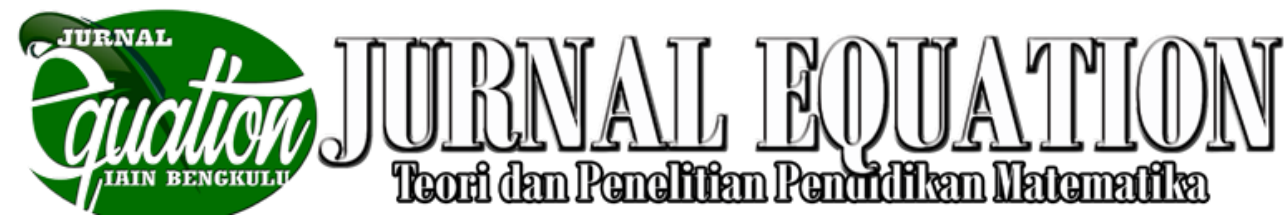

Volume 2 Nomor 1, Maret 2019, ISSN 2599-3291 (Cetak), ISSN 2614-3933 (Online)

sebagian siswa tidak memperhatikan penjelasan guru. Hal ini menjadikan kegiatan belajar mengajar tidak efektif, karena guru harus mengulang menjelaskan materi kepada siswa yang tidak memperhatikan pembelajaran. Proses belajar pun dinilai tidak menyenangkan, terbukti sebagian anak lebih memilih asyik dengan dunianya sendiri. Metode konvensional saat ini memang masih sangat digemari dalam proses pembelajaran di sekolah termasuk di SD Negeri 08 Rejang Lebong. Menurut salah satu guru matematika yang mengajar di sana yaitu Ibu Mutia menyatakan bahwa pengajaran matematika itu tidak bisa dilepaskan dari metode konvensional sebab siswa tidak bisa dilepaskan dari peranan guru dalam menyampaikan materi secara langsung. Namun, hal ini sudah tidak sesuai lagi dengan perkembangan zaman, siswa saat ini harus dituntut lebih aktif dari gurunya sendiri agar siswa memahami apa yang ia pelajari baik melalui diskusi, kerjasama, menemukan, atau memecahkan masalah. Namun demikian, konvensional juga tidak bisa dihilangkan begitu saja, konvensional akan lebih baik jika dikombinasikan dengan metode pembelajaran, media pembelajaran, atau permainan matematika.

Belajar matematika sebenarnya tidaklah terlalu susah seperti persepsi para siswa saat ini, karena pada dasarnya setiap mata pelajaran yang memang kita mau pelajari atau adanya keinginan belajar pada diri kita sendiri pasti semuanya akan mudah untuk diterima dan dimengerti, tetapi kebanyakan dari siswa selalu mengganggap matematika itu adalah pelajaran yang sulit dan sering kali dianggap sebagai momok yang sangat menakutkan. Ketika siswa mengikuti proses pembelajaran matematika yang berlangsung di sekolah, mereka merasa jenuh akan pelajaran matematika, sama sekali tidak tertarik, malas belajar karena matematika dianggap ilmu yang monoton, yang hanya merupakan kumpulan angka-angka dan rumus yang tidak dapat dimanfaatkan dalam kehidupan. Mereka berpandangan belajar matematika di sekolah hanya sekedar diajari bagaimana siswa dapat menyelesaikan soal dengan baik yang kemudian menyebabkan munculnya sifat kebencian terhadap matematika. Terkait dengan persepsi berlebihan terhadap mata pelajaran matematika saat ini, dapat ditemukan beberapa penyebab siswa-siswi jenuh terhadap pelajaran matematika khususnya di SDN 8 Rejang Lebong diantaranya adalah penekanan berlebihan pada hafalan semata, penekanan pada kecepatan atau berhitung, pengajaran yang monoton, dan kurangnya variasi dalam proses belajar mengajar matematika. 


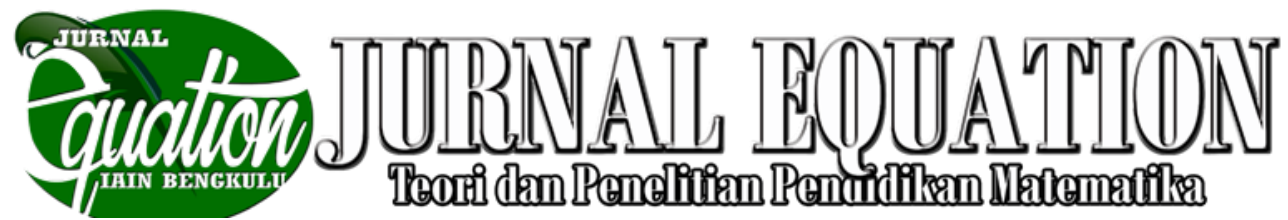

Volume 2 Nomor 1, Maret 2019, ISSN 2599-3291 (Cetak), ISSN 2614-3933 (Online)

Terutama dengan pembelajaran operasi hitung matematika pada anak sekolah dasar, karena pada dasarnya operasi hitung merupakan dasar atau modal awal peserta didik dalam segala pengajaran matematika di sekolah. Apabila pengoperasian anak dalam tingkat sekolah dasar bermasalah maka dalam tingkatan selanjutnya sampai ke sekolah tingkat atas atau sampai tingkat lanjutan akan mengalami kesulitan dalam mengoperasikannya, terutama lagi pada tingkatan atas sudah lebih banyak materi atau pengajaran yang lebih abstrak lagi terhadap matematika. Oleh karena itu, sangat penting bahwa siswa sekolah dasar harus memahami dan lebih mengusai operasi hitung matematika.

Struktur kurikulum 2013 pada tingkat SD/MI memuat delapan mata pelajaran yang terbagi menjadi dua kelompok, yaitu kelompok $\mathrm{A}$ adalah kelompok yang konten mata pelajarannya dikembangkan oleh pusat dan kelompok B adalah kelompok mata pelajaran yang kontennya dikembangkan oleh pusat dan dilengkapi konten lokal yang dikembangkan oleh pemerintah daerah (Kemendikbud, 2013) Matematika yang menjadi bagian dari mata pelajaran kelompok A memiliki tujuan pembelajaran di tingkat SD/MI adalah agar siswa mengenal angkaangka sederhana, operasi hitung sederhana, pengukuran, dan bidang. Objek langsung yang diperoleh dalam belajar matematika adalah fakta, keterampilan, konsep, dan aturan. Kemampuan matematika yang diperlukan dalam kehidupan sehari-hari termasuk kemampuan operasi hitung, yang sangat diperlukan untuk menyelesaikan persoalan-persoalan yang ditemukan dalam kehidupan sehari-hari yang bersifat matematis (Sulaimah, 2013: 2)

Terkait dengan pembelajaran matematika pada anak Sekolah Dasar akan terasa sulit jika mengajarkan operasi hitung matematika hanya secara teoritis saja, karena karakteristik anak pada anak usia sekolah dasar adalah bermain. Lemahnya kemampuan operasi hitung siswa dikarenakan proses pembelajaran yang kurang menarik dan kurangnya variasi penerapan metode pembelajaran. Oleh karena itu, untuk mengatasi beberapa penyebab ini maka guru sangat berperan penting dalam menggunakan metode dan media pembelajaran. Karena begitu pentingnya peran guru dalam mengatasi masalah belajar siswa maka metode pengajaran matematika pun perlu disesuaikan dan diperbaharui.

Permainan atau game saat ini merupakan suatu alternatif dan sesuatu yang paling diminati oleh setiap anak atau siswa 


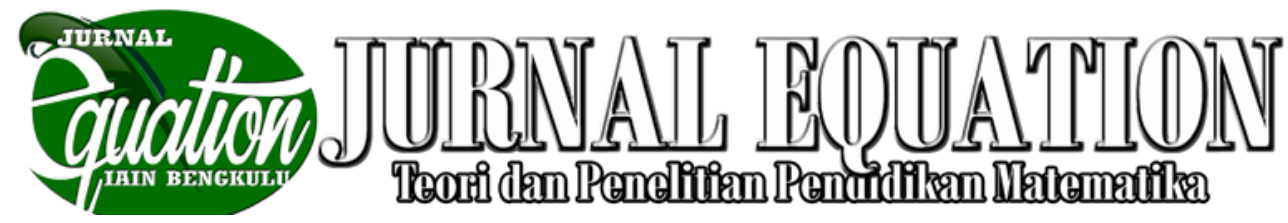

Volume 2 Nomor 1, Maret 2019, ISSN 2599-3291 (Cetak), ISSN 2614-3933 (Online)

karena pada tingkat usia sekolah dasar karakteristik anaknya adalah suka bermain dan lebih tertarik pada sesuatu yang nyata atau bisa dilihat dengan panca indera. Remi salah satunya adalah suatu permainan yang sering sekali dijumpai dan mudah sekali untuk ditemukan dalam kehidupan seharihari yang bisa disulap menjadi media/ game pembelajaran pada anak SD agar siswa akan lebih tertarik dalam proses pembelajaran matematika. Hal ini senada dengan yang dinyatakan oleh Pitadjeng dalam Sulaimah (2013) seharusnya proses belajar yang baik itu dapat membangkitkan kegiatan belajar yang efektif, bermakna dan menyenangkan. Menurut Kline, belajar akan efektif jika dilakukan dalam suasana yang menyenangkan (Sulaimah, 2013: 3). Dengan demikian, pembelajaran dengan menggunakan math game dapat menjadi suatu alternatif dan sekaligus menjadi bagian dari metode pembelajaran yang aktif, kreatif dan asik. Adapun math game yang dapat diterapkan dalam penelitian ini adalah permainan dengan menggunakan kartu remi yang didesain menggunakan bilanganbilangan dan operasi hitung matematika yang kemudian disebut dengan Kartu Remi Berhitung (Karetung). Penggunaan kartu ini dapat melatih pola pikir siswa dalam berhitung. Mengingat pentingnya penggunaan kartu tersebut dan masalah yang terjadi dalam operasi hitung siswa, maka penulis tertarik untuk melakukan penelitian menggunakan kartu remi berhitung di SDN 8 Rejang Lebong dengan judul "Penggunaan Math Game Kartu Remi Berhitung (Karetung) terhadap Kemampuan Operasi Hitung Siswa".

Menurut Abraham S Lunchins dan Edith N Luchins, matematika dapat dijawab secara berbeda-beda tergantung pada bilamana pertanyaan itu dijawab, dimana dijawabnya, siapa yang menjawabnya, dan apa sajakah yang dipandang termasuk dalam matematika. Berbagai pendapat muncul tentang pengertian matematika tersebut, dipandang dari pengetahuan dan pengalaman masing- masing yang berbeda.

Ada yang mengatakan bahwa matematika itu bahasa simbol; matematika adalah bahasa numerik; matematika adalah bahasa yang dapat menghilangkan sifat kabur, majemuk, emosional; matematika adalah metode berpikir logis; matematika adalah sarana berpikir; matematika adalah logika pada masa dewasa; matematika adalah ratunya ilmu dan sekaligus menjadi pelayannya; matematika adalah suatu sains yang bekerja menarik kesimpulankesimpulan yang perlu ; matematika adalah sains formal yang murni; matematika adalah sains yang memanipulasi simbol; matematika adalah ilmu tentang bilangan dan ruang 


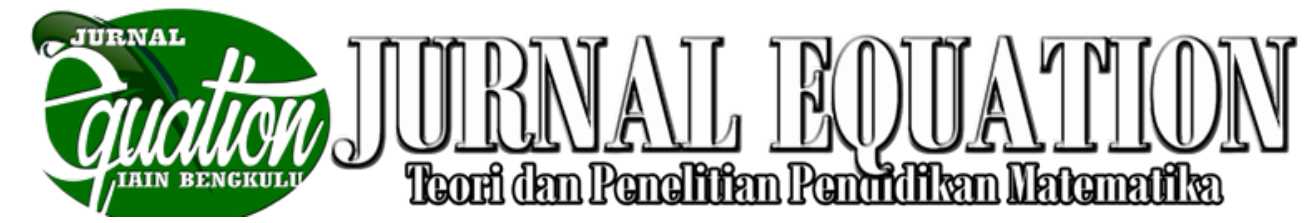

Volume 2 Nomor 1, Maret 2019, ISSN 2599-3291 (Cetak), ISSN 2614-3933 (Online)

matematika adalah ilmu yang mempelajari hubungan pola, bentuk, dan struktur; matematika adalah ilmu yang abstrak dan deduktif; matematika adalah aktivitas manusia (Erman Suherman, 2001:15).

James dan James (1976) dalam

(Erman Suherman, 2001:16) mengatakan bahwa matematika adalah ilmu tentang logika mengenai bentuk, susunan, besaran, dan konsep-konsep yang berhubungan satu dengan yang lainnya dengan jumlah yang banyak yang terbagi ke dalam tiga bidang, yaitu aljabar, analisis, dan geometri.

Menurut Asep Jihad (Destiana Vidya Prastiwi, 2011: 33-34) dapat diidentifikasi bahwa matematika jelas berbeda dengan mata pelajaran lain dalam beberapa hal berikut, yaitu:

a. objek pembicaraannya abstrak, sekalipun dalam pengajaran di sekolah anak diajarkan benda konkrit, siswa tetap didorong untuk melakukan abstraksi; pembahasan mengandalkan tata nalar, artinya info awal berupa pengertian dibuat seefisien mungkin, pengertian lain harus dijelaskan kebenarannya dengan tata nalar yang logis;

b.pengertian/konsep atau pernyataan sangat jelas berjenjang sehingga terjaga konsistennya;

c. melibatkan perhitungan (operasi); d.dapat dipakai dalam ilmu yang lain serta dalam kehidupan sehari-hari.

Berdasarkan kajian teori di atas dapat disimpulkan bahwa matematika adalah ilmu pengetahuan yang dapat ditinjau dari segala sudut dan matematika bisa memasuki seluruh segi kehidupan manusia, dari yang paling sederhana sampai kepada yang paling kompleks dan matematika itu sendiri dapat diperoleh dengan bernalar yang menggunakan istilah yang didefinisikan dengan cermat, jelas, dan akurat, representasinya dengan lambang-lambang atau simbol dan memiliki arti serta dapat digunakan dalam pemecahan masalah yang berkaitan dengan bilangan.

\section{Kemampuan Operasi Hitung}

Taksonomi Bloom dalam Dimyati (2012, hal 298) menjelaskan jika belajar dibagi menjadi tiga ranah, yang pertama adalah ranah kognitif dimana ranah ini mencakup kegiatan mental (otak). Menurut Bloom segala upaya menyangkut aktivitas otak adalah termasuk dalam ranah kognitif. Kemampuan operasi hitung merupakan salah satu kemampuan kognitif yang harus ditingkatkan siswa dalam belajar matematika. Kemampuan adalah kesanggupan, kecakapan, kekuatan (KBBI, 1990: 522).

Ada beberapa operasi hitung yang dapat dikenalkan pada bilangan. Operasioperasi tersebut adalah: (1) Penjumlahan; (2) 


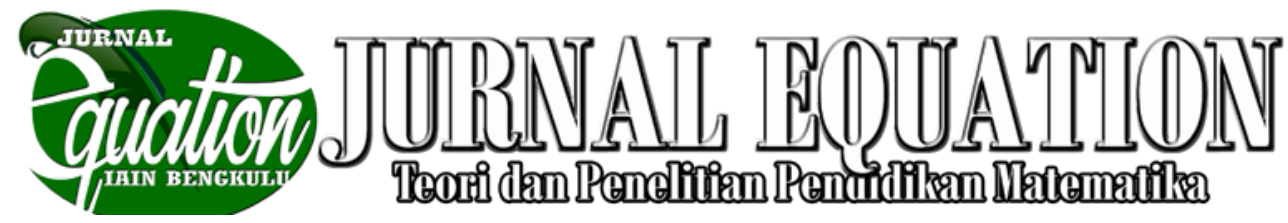

Volume 2 Nomor 1, Maret 2019, ISSN 2599-3291 (Cetak), ISSN 2614-3933 (Online)

Pengurangan; (3) Perkalian; (4) Pembagian.

Operasi-operasi tersebut memiliki kaitan yang sangat erat sehingga pemahaman konsep dan keterampilan melakukan operasi yang satu akan mempengaruhi pemahaman konsep dan keterampilan operasi yang lain (Muchtar A.karim, 1996:99).

Berdasarkan kajian teori di atas, dapat disimpulkan bahwa kemampuan operasi hitung adalah kecakapan yang harus dikuasai siswa dalam menyelesaikan tugas pengerjaan hitung dengan tepat.

Operasi hitung terdiri dari empat pengerjaan dasar yang saling berkaitan, sehingga penguasaan operasi yang satu akan mempengaruhi operasi lainnya. Penguasaan operasi ini meliputi pemahaman konsep dan keterampilan melakukan operasi (Sri Subarinah, 2006: 28). Keempat pengerjaan dasar tersebut dapat dijelaskan sebagai berikut:

a. Penjumlahan

Operasi penjumlahan dalam matematika dilambangkan dengan tanda " + ". Makna dari operasi penjumlahan adalah menggabungkan dua kelompok (himpunan) (Sri Subarinah, 2006:29). Jika kelompok A memiliki 5 kelereng digabungkan dengan kelompok B yang memiliki 7 kelereng, maka diperoleh jumlah total kelereng sebanyak 12 . Hal ini menjelaskan bahwa $5+7=12$.
Operasi penjumlahan dibagi menjadi dua yaitu penjumlahan tanpa teknik atau atau penjumlahan dasar dan penjumlahan menggunakan teknik-teknik tertentu. Penjumlahan dasar adalah menjumlahkan dua objek atau dua angka yang digabung menjadi satu. Sedangkan penjumlahan lanjut adalah penjumlahan menggunakan teknik menyimpan atau tanpa teknik menyimpan.

Penjumlahan dengan teknik menyimpan tidaklah semudah mengajarkan penjumlahan tanpa teknik menyimpan. Kemampuan prasyarat yang harus dimiliki siswa dalam mempelajari penjumlahan dengan teknik menyimpan adalah penjumlahan tanpa teknik menyimpan (Heruman, 2017:11).

b. Pengurangan

Operasi pengurangan dilambangkan dengan tanda "-". Operasi pengurangan merupakan lawan atau kebalikan dari operasi penjumlahan. Jika pada operasi penjumlahan dilakukan penggabungan dua kelompok (himpunan), maka pada operasi pengurangan dilakukan pengambilan kelompok baru, yaitu pembentukan kelompok baru (Sri Subarinah, 2006: 30). Misalnya, dari kelompok A memiliki kelereng 7 buah dan akan diberi 3 kelereng ke kelompok B. Hal ini menunjukkan makna operasi pengurangan 7

$-3=4$. Operasi pengurangan juga

Annisa Bunga Pertiwi Pengunaan Math Game.... 


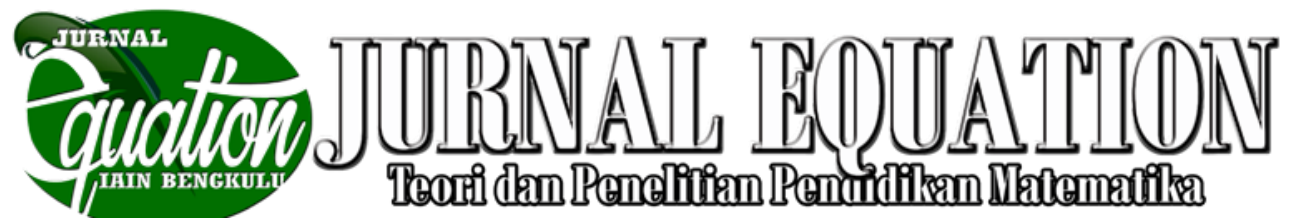

Volume 2 Nomor 1, Maret 2019, ISSN 2599-3291 (Cetak), ISSN 2614-3933 (Online)

dapat dikenalkan dengan selisih banyaknya anggota dua kelompok (Sri Subarinah, 2006: 30). Misalnya kelompok A beranggotakan 7 orang dan kelompok B beranggotakan 3 orang. Setiap anggota kelompok A dipasangkan dengan anggota kelompok $B$, maka akan terdapat 4 anggota kelompok $A$ yang tidak berpasangan dengan kelompok $\mathrm{B}$. Hal ini juga menunjukkan operasi pengurangan $7-3=4$. Selain itu, operasi pengurangan dapat pula dikenalkan sebagai lawan operasi penjumlahan, yaitu $a-b=c$, sama artinya dengan $a=b+c$. Contoh pengurangan $12-6=6$ sama artinya dengan penjumlahan $12=6+6$.

Operasi pengurangan dibagi menjadi dua yaitu pengurangan tanpa teknik atau pengurangan dasar dan pengurangan menggunakan teknik-teknik tertentu. Pengurangan dasar adalah mengurangkan sebagian dari sebuah kumpulan atau objek. Sedangkan pengurangan lanjut adalah pengurangan menggunakan teknik meminjam atau tanpa teknik meminjam.

c. Perkalian

Operasi perkalian dilambangkan dengan tanda " $x$ ". Operasi perkalian pada bilangan cacah diartikan sebagai penjumlahan berulang (Sri Subarinah, 2006:31). Pada prinsipnya, perkalian sama dengan penjumlahan secara berulang oleh karena itu, kemampuan prasyarat yang harus dimiliki siswa sebelum perkalian adalah penguasaan penjumlahan (Heruman, 2007:22)

Perkalian $a \times b$ diartikan sebagai penjumlahan bilangan b sebanyak a kali. Jadi $a \times b=b+b+b+\ldots+b$ sebanyak $a$

Contohnya:

$$
7 \times 3=3+3+3+3+3+3+3=21
$$

dan $3 \times 2=2+2+2=6$.

Seperti operasi yang lainnya, operasi perkalian dibagi menjadi dua hal, yaitu perkalian dasar dan perkalian lanjut. Perkalian dasar yang dimaksud adalah perkalian dua bilangan satu angka, sedangkan perkalian lanjut adalah perkalian yang melibatkan paling tidak sebuah bilangan dua angka.

$$
\text { d. Pembagian }
$$

Operasi pembagian dilambangkan dengan tanda ":". Operasi pembagian adalah lawan dari operasi perkalian. Sehingga $a: b=$ $c$ artinya sama dengan $a=b \times c$. Dengan demikian $a: b=\ldots$ artinya mencari bilangan cacah yang jika dikalikan dengan $b$ hasilnya sama dengan a.

Pembagian merupakan lawan dari perkalian. Pembagian disebut juga pengurangan berulang sampai habis. Kemampuan prasyarat yang harus dimiliki siswa dalam mempelajari konsep pembagian 


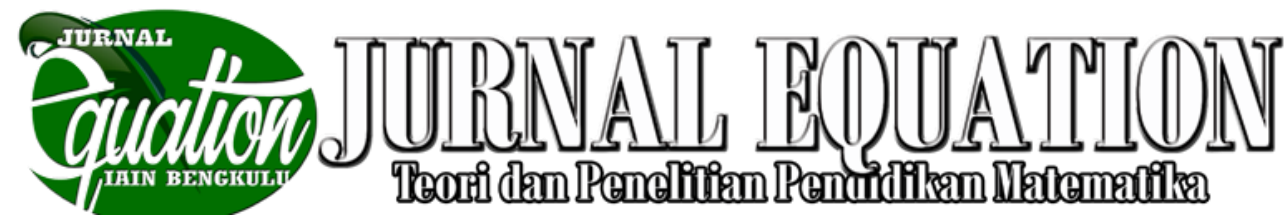

Volume 2 Nomor 1, Maret 2019, ISSN 2599-3291 (Cetak), ISSN 2614-3933 (Online)

adalah pengurangan dan perkalian (Heruman, 2007:26). Pembagian $a: b=c$ artinya $a-b-b-b-b-b=0$, sebanyak $c$. Sehingga $9: 3=\ldots$, artinya kita mencari bilangan yarg: 3 makan banyaknya pengurangan 9 oleh 3 sehingga hasil akhirnya 0 . Karena $9-3-3-3=0$, maka hasil pembagian 9 oleh 3 adalah 3 , dimana 3 menunjukkan banyaknya pengurangan dengan angka 3.

\section{Metode Permainan}

Metode permainan merupakan hal yang sangat dekat dengan dunia anak. Menurut Simanjuntak (2008:6.2) bagi anak, belajar adalah bermain, bermain adalah belajar. Peraturan Pemerintah Nomor 19 tahun 2005 tentang Standar Nasional Pendidikan (SNP) yang harus dipahami seorang pendidik, salah satu standar yang harus dikembangkan adalah standar proses.

Standar proses adalah standar nasional pendidikan yang berkaitan dengan pelaksanaan pembelajaran pada satuan pendidikan untuk mencapai kompetensi lulusan. Standar proses meliputi perencanaan proses pembelajaran, pelaksanaan proses pembelajaran, penilaian hasil pembelajaran, dan pengawasan hasil proses. Pembelajaran untuk terlaksananya proses pembelajaran yang efektif dan efisien.

Permainan matematika adalah suatu kegiatan yang menggembirakan yang dapat menunjang tercapainya tujuan instruksional matematika. Tujuan ini dapat menyangkut aspek kognitif, psikomotorik, atau afektif. Walaupun permainan matematika menyenangkan penggunaannya harus dibatasi, tidak dilaksanakan seingatnya saja. Barangkali sekali-kali dapat juga diberikan untuk mengisi waktu, mengubah suasana "tekanan tinggi", menimbulkan minat, dan sejenisnya. Seharusnya direncanakan dengan tujuan instruksional yang jelas, tepat penggunaannya, dan tepat pula waktunya. Permainan yang mengandung matematika dapat meningkatkan keterampilan, penanaman konsep, pemahaman, dan pemantapannya; meningkatkan kemampuan menemukan memecahkan masalah, dan lain-lainnya (Erman Suherman, 2003:216).

Menurut Sudjana (2010:140), keunggulan metode permainan adalah menumbuhkan kegembiraan dan tidak melelahkan dalam belajar; kompetisi dan ingin menang dirasakan oleh para peserta didik; dapat menggunakan alat-alat yang mudah didapat di daerah setempat, murah dan gampang digunakan; ganjaran bagi pemenang dirasakan langsung; dan penilaian bersama oleh pengamat dan pemain.

Pengaruh Metode Permainan terhadap Kemampuan Operasi Hitung semakin banyak pendidik dan psikolog yang percaya bahwa Pengunaan Math Game.... 


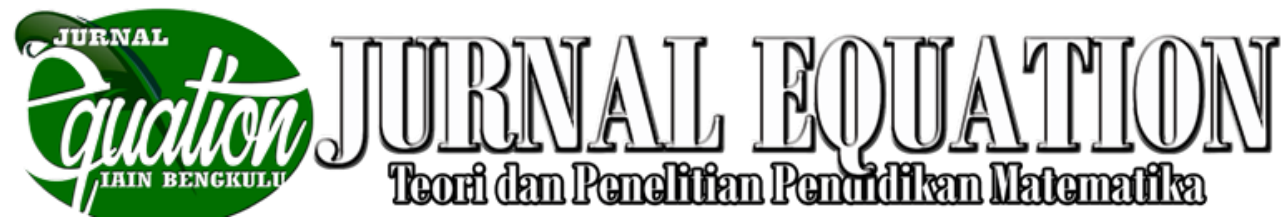

Volume 2 Nomor 1, Maret 2019, ISSN 2599-3291 (Cetak), ISSN 2614-3933 (Online)

anak-anak pra sekolah dan sekolah dasar belajar paling baik melalui metode pengajaran yang aktif dan partisipatif, seperti permainan dan drama (Santrock, 2007:243). Dengan berpartisipasi aktif dalam pembelajaran, anak diharapkan lebih mudah memahami materi yang diajarkan. Dalam Andang Ismail (2006:25) para ahli pendidikan anak dalam risetnya mengatakan bahwa cara belajar anak yang paling efektif ada pada permainan anak, yaitu dengan bermain dalam kegiatan belajar mengajarnya. Bermain sebagai bentuk kegiatan belajar adalah bermain yang kreatif, menyenangkan dan bersifat mendidik (Andang Ismail, 2006: 26). Metode permainan merupakan suatu metode pembelajaran yang dikemas dalam bentuk permainan. Dengan menerapkan metode permainan dalam pembelajaran akan tercipta suasana belajar yang menyenangkan. Menurut Dienes (Pitadjeng, 2006:31) permainan matematika sangat penting sebab operasi hitung matematika dalam permainan tersebut menunjukkan aturan secara konkret dan lebih membimbing dan menajamkan pengertian matematika pada anak didik.

Metode permainan sama seperti metode-metode mengajar lainnya memerlukan perumusan tujuan instruksional yang jelas, penilaian topik atau subtopik, perincian kegiatan belajar mengajar dan lain- lainya. Disarankan dilakukan evaluasi dan penelitian mengingat informasi di negara lain menunjukan bahwa permainan matematika menarik bagi siswa dan dapat menantang siswa untuk belajar lebih lanjut (Erman Suherman, 2003:220).

Kemampuan operasi hitung yang perlu dikuasai siswa berupa kecakapan dalam menyelesaikan soal dengan tepat. Selama ini untuk menguasai kemampuan operasi hitung misal penjumlahan dan pengurangan, dalam proses pembelajaran terkadang siswa diajarkan untuk menghafal tanpa memahami dengan benar konsep yang sebenarnya. Penerapan metode permainan dalam proses belajar mengajar menyajikan suasana belajar yang berbeda, yang membuat peserta lebih nyaman belajar. Sehingga siswa dapat meningkatkan kemampuan operasi hitungnya dengan bermain sambil belajar, karena bermain adalah sarana belajar yang paling efektif dan menyenangkan (Andang Ismail, 2006: 9).

\section{Media kartu}

Permainan kartu bilangan merupakan salah satu benda yang dapat dimanfaatkan sebagai permainan edukatif. Media kartu yang dikemas dalam bentuk permainan edukatif diharapkan dapat menjadikan proses belajar lebih menarik dan siswa terlibat aktif dalam kegiatan pembelajaran (Erlina 


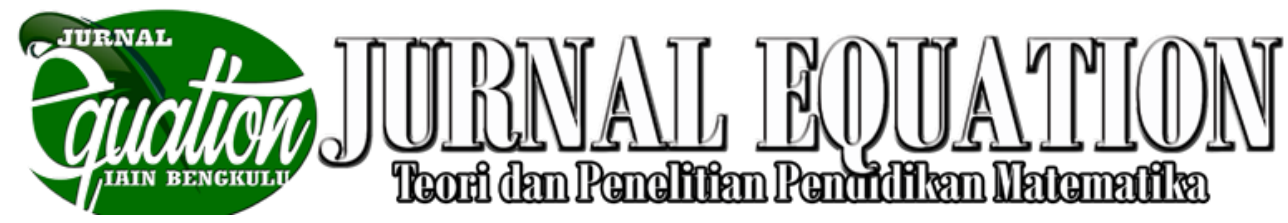

Volume 2 Nomor 1, Maret 2019, ISSN 2599-3291 (Cetak), ISSN 2614-3933 (Online)

Budihartanti, 2011: 43). Media permainan kartu bilangan adalah alat perantara yang digunakan dalam permainan dengan menggunakan kertas yang dibentuk sesuai dengan keperluan terdiri dari kumpulan beberapa angka yang mengandung makna untuk mencapai tujuan pembelajaran (Abdul Muin, 2012: 35). Berdasarkan kajian teori di atas penulis menggunakan metode permainan kartu sebagai metode untuk meningkatkan kemampuan operasi hitung siswa yaitu Karetung.

Karetung yaitu permainan kartu yang diadaptasi dari permainan kartu remi. Karetung berisi operasi-operasi hitung dalam matematika seperti penjumlahan, pengurangan, perkalian dan pembagian yang berjumlah sebanyak 54 buah kartu, yang terdiri dari 13 kartu love, 13 kartu wajik, 13 kartu sekop,13 kartu keriting dan 2 kartu joker yang dilambangkan dengan variable $X$ dan Y. Karetung pada penulisan ini dibuat dengan kertas foto berukuran $8.7 \times 6.2 \mathrm{~cm}$.

Permainan karetung dilakukan dengan aturan sebagai berikut:

a. permainan KARETUNG dimainkan sebanyak dua orang atau lebih;

b. kocok karetung hingga agar kartu tersebut teracak;

c. bagikan kartu masing-masing orang sebanyak 5 kartu;

d. buka satu kartu sebagai pembuka permainan karetung;

e. pemain mencari kartu yang mempunyai gambar yang sama dengan kartu pembuka permainan karetung;

f. sisa kartu di gunakan untuk pencabutan apabila dari kelima kartu tersebut tidak terdapat kartu yang sama gambarnya. Dengan ketentuan dimana hasil yang lebih besar nilainya akan memasang kartu selanjutnya untuk melajutkan permainan;

g. dikatakan memenangkan permainan apabila kartu yang dimiliki salah seorang pemain telah habis. Apabila tedapat lebih dari dua pemain maka pemainan dapat dilanjutkan sehingga pemenangnya tidak hanya satu siswa saja.

\section{Hipotesis Penelitian}

Hipotesis merupakan suatu jawaban yang bersifat sementara yang dapat disimpulkan dari permasalahan penelitian, sampai terjawab melalu pembuktian data yang terkumpul (Arikunto S. , Prosedur Penelitian Suatu Pengantar praktik, 1985). Dari rumusan masalah penelitian di atas, maka hipotesis penelitian ini adalah:

$\mathrm{HO}$ :

Tidak

terdapat pengaruh Math Game Kartu Remi 


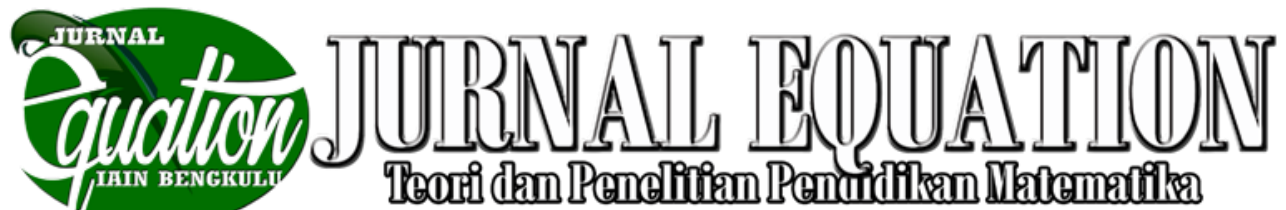

Volume 2 Nomor 1, Maret 2019, ISSN 2599-3291 (Cetak), ISSN 2614-3933 (Online)

Berhitung (Karetung) terhadap Kemampuan

Operasi Hitung Siswa

H1 : Terdapat pengaruh Math Game

Kartu Remi Berhitung (Karetung) terhadap

Kemampuan Operasi Hitung Siswa

METODE PENULISAN

Jenis penelitian

Jenis penelitian yang digunakan dalam penelitian ini yaitu quasi eksperimen. Penelitian quasi eksperimen diartikan sebagai eksperimen semua yang mendekati percobaan sungguhan dimana tidak mungkin mengadakan kontrol atau memanipulasikan semua variabel telah relevan. Selanjutnya, penelitian quasi eksperimen juga diartikan sebagai penelitian yang mengandung hubungan kausal atau sebab akibat (Darmawan, 2013). Sedangkan desain penelitian yang digunakan yaitu one group pretest-postest design karena dalam rancangan ini digunakan satu kelompok subjek. Pertama-tama dilakukan pengukuran sebagai tes awal (pretest), lalu dikenakan perlakuan tertentu untuk jangka waktu tertentu, kemudian dilakukan pengukuran untuk kedua kalinya sebagai tes akhir (posttest) (Budiyono 2003).

Rancangan tersebut dapat digambarkan sebagai berikut: (Budiyono 2003)
Tabel 1. Rancangan Penelitian

\begin{tabular}{|l|l|l|}
\hline $\mathrm{T} 1$ & $\mathrm{X}$ & $\mathrm{T} 2$ \\
\hline
\end{tabular}

Tempat dan Waktu Penelitian

Tempat Penelitian

Adapun yang menjadi tempat penelitian ini adalah SDN 8 Rejang lebong Kabupaten Rejang Lebong

Waktu Penelitian

Waktu penelitian yang dilakukan yaitu pada bulan Januari - Februari 2019 yaitu selama 4 (empat) kali pertemuan dengan rincian: 2 (dua) kali pertemuan menerapkan kartu remi berhitung, 1 (satu) kali pertemuan pre test dan 1 (kali) pertemuan post test.

\section{Populasi dan Sampel}

Populasi

Menurut Suharsimi, populasi adalah keseluruhan subyek penelitian (S. Arikunto, Manajemen Penelitian 2010). Populasi aadalah sekelompok subyek, baik manusia, gejala nilai tes, baik benda ataupun peristiwa. Adapula yang mengatakan bahwa populasi itu adalah keseluruhan subyek penelitian (S. Arikunto, Prosedur Penelitian 2002). Dari penjelasan di atas dapat disimpulkan bahwa populasi adalah keseluruhan suatu subyek yang ada di dalam penelitian yang dilakukan. Adapun populasi dari penelitian ini adalah 


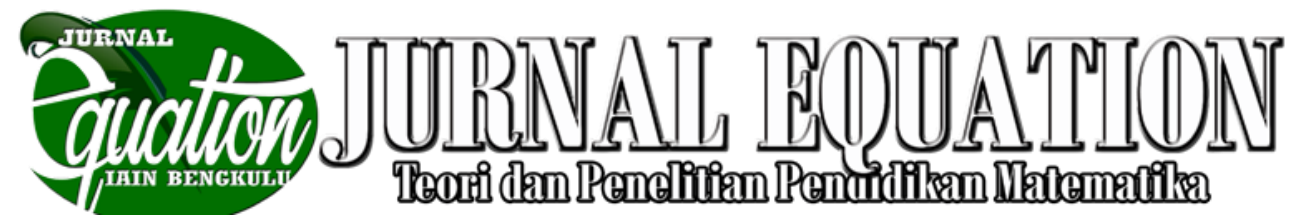

Volume 2 Nomor 1, Maret 2019, ISSN 2599-3291 (Cetak), ISSN 2614-3933 (Online)

siswa kelas V SDN 8 Rejang Lebong.

Sampel

Sampel adalah sebagian atau wakil populsi yang diteliti (S. Arikunto 2013). Sampel adalah bagian dari jumlah dan karakteristik yang dimiliki populasi. Kesimpulan yang dipelajari dari sampel, diberlakukan untuk seluruh populasi. Karena itu, sampel yang diambil dari populasi harus benar-benar representatif (Syarnubi 2014).

Teknik pengambilan sampel pada penelitian ini adalah sampling jenuh yaitu teknik penentuan sampel bila semua anggota populasi digunakan sebagai sampel (Sugiyono 2014). Sehubungan dengan penelitian ini yang dijadikan sampel adalah seluruh siswa kelas V SDN 8 Rejang Lebong yang berjumlah 14 orang. Datanya sebagai berikut.

Tabel 2. Sampel penelitian

\begin{tabular}{|c|l|c|}
\hline $\mathrm{N}$ & $\begin{array}{l}\text { Jenis } \\
\text { Kelamin }\end{array}$ & Jumlah \\
\hline 1 & Laki-laki & 7 \\
\hline 2 & $\begin{array}{l}\text { Peremp } \\
\text { uan }\end{array}$ & 7 \\
\hline & Total & 14 \\
\hline
\end{tabular}

(Sumber: Guru Kelas V SDN 8

Rejang Lebong)

\section{Teknik Pengumpulan Data}

Adapun teknik pengumpulan data yang akan digunakan dalam penelitian ini adalah sebagai berikut:

\section{Observasi}

Secara umum, pengertian observasi adalah cara menghimpun bahan- bahan keterangan (data) yang dilakukan dengan mengadakan pengamatan dan pencatatan secara sistematis terhadap fenomena-fenomena yang sedang dijadikan sasaran pengamatan (Sudijono 2006). Dalam hal ini peneliti menggunakan observasi partisipatif yaitu peneliti terlibat dengan kegiatan sehari-hari orang yang sedang diamati atau yang digunakan sebagai sumber penelitian. Observasi dalam hal ini digunakan untuk memperoleh data Math Games Karetung terhadap kemampuan operasi hitung siswa kelas V SDN 8 Rejang Lebong. Adapun observasi ini akan dinilai oleh dua observer yaitu Sindi Destrianti dan Saumi Ramadhani.

\section{Tes}

Tes merupakan seperangkat alat rangsangan yang diberikan kepada seseorang dengan maksud untuk mendapatkan jawaban yang dapat 


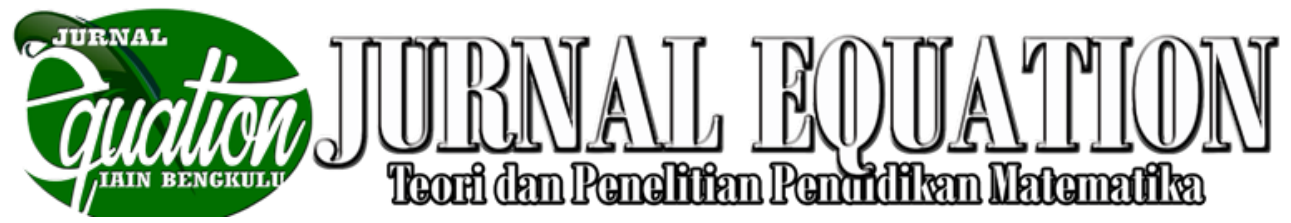

Volume 2 Nomor 1, Maret 2019, ISSN 2599-3291 (Cetak), ISSN 2614-3933 (Online)

dijadikan dasar bagi penetapan (nilai)

biji skor seseorang berkenaan dengan karakteristik variabel tertentu yang hendak diukur (Syarnubi, Metode Penelitian Kuantitatif dan Kualitatif 2011). Tes adalah alat atau prosedur yang digunakan dalam pengukuran dan penilaian.

Jenis tes yang peneliti gunakan dalam penelitian ini adalah salah satu dari bentuk tes obyektif yaitu tes pilihan ganda (multiple choice test). Soal tes bentuk pilihan ganda terdiri atas pembawa pokok persoalan dan pilihan jawaban. Adapun jumlah soal dalam penelitian ini adalah 20 soal.

\section{Dokumentasi}

Dimaksud dengan dokumentasi dalam pelaksanaan penelitian adalah melakukan pencarian data dengan menelaah dokumen-dokumen atau informasi yang tercatat dalam buku prosedur penelitian dikatakan bahwa "dokumentasi adalah mencari data mengenai hal-hal yang berupa catatan, transkip, buku, surat kabar, majalah dan sebagainya" (Daryawan Syah, 2007). Adapun dokumentasi yang dimaksud disini adalah foto kegiatan pelaksanaan pembelajaran, RPP, dan silabus.

\section{Uji Coba Instrumen}

\section{Uji Validitas}

Validitas adalah suatu alat ukur yang menunjukkan tingkat kevalidan atau keshahihan suatu instrumen. Suatu instrumen yang valid atau shahih mempunyai validitas yang tinggi. Sebaliknya, instrumen yang kurang valid memiliki validitas rendah (Sudijono, Pengantar Evaluasi Pendidikan 2013). Pengujian validitas menggunakan korelasi produk momen, apabila rhitung q rtabel maka butir pernyataan dapat dikatakan valid. Adapun rumusnya yaitu:

\section{a.Uji Reliabilitas}

Reliabilitas adalah ketetapan atau keajengan alat tersebut dalam menilai apa yang dinilainya. Artinya, kapan pun alat penilaian tersebut digunakan akan memberikan hasil yang relatif sama (Sudjana 2009). Reliabilitas mengandung pengertian bahwa suatu instrumen dapat dipercaya untuk digunakan sebagai pengumpulan data karena instrumen tersebut sudah baik. Pengujian reliabilitas ini menggunakan rumus Alpha Cronbach, yaitu sebagai berikut:

\section{Teknik Analisis Data}

Setelah data dikumpul maka langkah selanjutnya adalah 


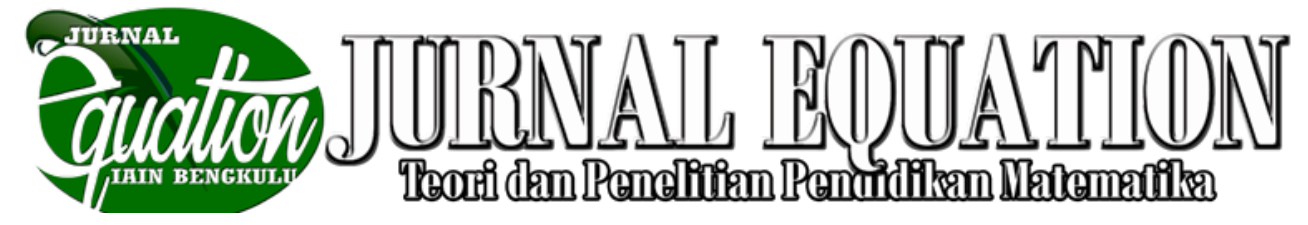

Volume 2 Nomor 1, Maret 2019, ISSN 2599-3291 (Cetak), ISSN 2614-3933 (Online)

melaksanakan analisis data guna membuktikan hipotesis yang telah peneliti ajukan. Data yang telah terkumpul kemudian dianalisis untuk dapat menjawab rumusan masalah dan hipotesis penelitian

\section{b.Uji Normalitas}

Uji normalitas dipergunakan untuk mengubah data dalam menentukan apakah sampel yang telah diuji berdistribusi normal atau tidak. Pada uji normalitas digunakan uji Liliefors dengan langkah-langkah sebagai berikut

\section{c.Uji Homogenitas}

Uji homogenitas dilakukan untuk mengetahui apakah data sampel berasal dari populasi yang variansnya sama (homogen). Teknik yang digunakan untuk uji homogenitas pada penelitian ini adalah uji Fisher.

\section{HASIL DAN PEMBAHASAN}

\section{Hasil Penelitian}

Dari hasil penelitian yang dilakukan maka diperoleh gambaran data tentang "Penggunaan math game kartu remi berhitung (karetung) terhadap kemampuan operasi hitung siswa" sebagai berikut :

Hasil Pretest dan Posttest
Hasil pretest diperoleh nilai tertinggi $=60$ dan nilai terendah $=5$ dari nilai maksimum 100 dengan jumah siswa 14 orang. Sedangkan hasil posttest diperoleh nilai tertinggi $=85$ dan nilai terendah $=60$ dari nilai maksimum 100 dengan jumlah siswa 14 orang. Berikut ini adalah hasil pretest dan posttest :

Tabel 3. Daftar Nilai Pretest dan Posttest Siswa

\begin{tabular}{|l|c|c|}
\hline \multicolumn{1}{|c|}{ Nama } & $\begin{array}{c}\text { Pretest } \\
\text { (X) }\end{array}$ & $\begin{array}{l}\text { Poste } \\
\text { st (Y) }\end{array}$ \\
\hline $\begin{array}{l}\text { Aisyah } \\
\text { Ramadina }\end{array}$ & 50 & 70 \\
\hline $\begin{array}{l}\text { Alivia } \\
\text { Kherani }\end{array}$ & 65 & 80 \\
\hline $\begin{array}{l}\text { Annisa } \\
\text { Zahratussi } \\
\text { ta }\end{array}$ & 70 & 85 \\
\hline $\begin{array}{l}\text { Aulia } \\
\text { Zahra } \\
\text { Andini }\end{array}$ & 60 & 80 \\
\hline $\begin{array}{l}\text { Didan } \\
\text { Adha } \\
\text { Brliansyah }\end{array}$ & 55 & 70 \\
\hline $\begin{array}{l}\text { Farhan } \\
\text { Alendra }\end{array}$ & 50 & 65 \\
\hline $\begin{array}{l}\text { Fina } \\
\text { Afriyati }\end{array}$ & 55 & 75 \\
\hline $\begin{array}{l}\text { Ketrin Dwi } \\
\text { Putri }\end{array}$ & 55 & 75 \\
\hline $\begin{array}{l}\text { Muhamma } \\
\text { d Galang } \\
\text { Ramadilia } \\
n\end{array}$ & 30 & 65 \\
\hline $\begin{array}{l}\text { Muhamma } \\
\text { d Naufal } \\
\text { Putra } \\
\text { Fajarianto }\end{array}$ & 70 & 70 \\
\hline $\begin{array}{l}\text { Raehan } \\
\text { Oktarizal }\end{array}$ & 45 & 70 \\
\hline $\begin{array}{l}\text { Refaldo } \\
\text { Martonio }\end{array}$ & 60 & 70 \\
\hline $\begin{array}{l}\text { Wali Wal } \\
\text { Aqdhi }\end{array}$ & 65 & \\
\hline $\begin{array}{l}\text { Nabila } \\
\text { Solehah }\end{array}$ & 40 & 70 \\
\hline
\end{tabular}




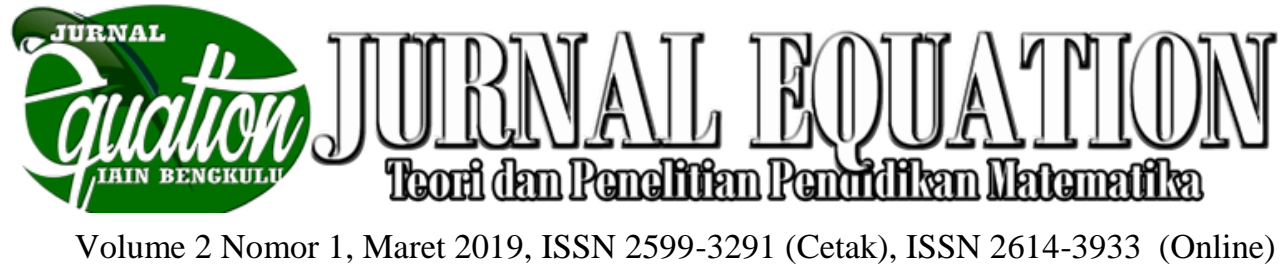

\section{Pengujian Instrumen}

1. Uji Validitas

Untuk mengetahui instrumen yang digunakan valid atau tidak maka

dilakukan uji validitas. Berdasarkan korelasi product moment jika rhitung $\geq$ rtabel. maka butir pernyataan dapat dikatakan valid. Dalam memberikan interpretasi

terhadap $r$ product moment digunakan rtabel dengan $\mathrm{db}=\mathrm{N}-\mathrm{nr}=14-2=12$ dan

memiliki taraf signifikasi 5\% sebesar 0,4575.

Dari butir soal yang diuji coba

terdapat 11 soal yang dinyatakan valid yaitu butir soal nomor 1, 2, 3, 4, 7, 9,

10, 13, 18, 19, 20 dan 9 soal yang dinyatakan tidak valid yaitu butir soal

nomor 5, 6, 8, 11, 12, 14, 15, 16, 17.

2. Uji Reliabilitas

Pada penelitian ini peneliti melakukan uji reliabilitas dengan menggunakan

Alpha Cronbach. Berdasarkan perhitungan uji reliabilitas yang diperoleh

koefisien reliabilitas tes yaitu sebagai berikut:

$$
\begin{aligned}
& r_{11}=\left[\frac{n}{n-1}\right]\left[1-\sum \frac{s_{i}{ }^{2}}{s_{t}{ }^{2}}\right] \\
& r_{11}=\left[\frac{20}{20-1}\right][1-0,39]=[1,056][0,61]=0,64
\end{aligned}
$$

Dari perhitungan diatas, diketahui bahwa koefisien reliabilitas tes sebesar 0,64. Dengan koefisien sebesar 0,64, maka soal tersebut memiliki reliabilitas tinggi/ soal tersebut memiliki nilai keajegan yang cukup tinggi (sedang).

\section{Uji Prasyarat}

\section{Uji Normalitas}

Pengujian data pretest dan data posttest sebagai berikut:

Tabel 4.Uji Normalitas

\begin{tabular}{|c|c|c|c|c|c|}
\hline $\mathbf{X}$ & $\mathbf{F}$ & $\mathbf{Z}=\frac{\boldsymbol{X}_{-\bar{L}-\bar{D}}}{\boldsymbol{S}}$ & $\mathbf{S}(\mathbf{Z})$ & $\mathbf{F}(\mathbf{Z})$ & $\mathbf{S}(\mathbf{Z})-\mathbf{F}(\mathbf{Z})$ \\
\hline 30 & 1 & -2.18618658 & 0,0714 & 0,0143 & 0,0571 \\
\hline 40 & 1 & -1.311711948 & 0,1428 & 0,0951 & 0,0477 \\
\hline 45 & 1 & -0.874474632 & 0,2142 & 0,1922 & 0,022 \\
\hline 50 & 2 & -0.437237316 & 0,3571 & 0,3300 & 0,0271 \\
\hline 55 & 3 & 0 & 0,5714 & 0 & $\mathbf{0 , 5 7 1 4}$ \\
\hline 60 & 2 & 0.437237316 & 0,7142 & 0,66640 & 0,0478 \\
\hline \hline 65 & 2 & -1.29283741 & 0,1428 & 0,0953 & 0,0475 \\
\hline 70 & 4 & -0.62247727 & 0,4286 & 0,26763 & $\mathbf{0 , 1 6 0 9 7}$ \\
\hline 75 & 3 & 0.047882867 & 0,6429 & 0,53983 & 0,10307 \\
\hline 80 & 3 & 0.718243006 & 0,8571 & 0,76424 & 0,09286 \\
\hline 85 & 1 & 1.388603145 & 0,9286 & 0,91774 & 0,01086 \\
\hline 90 & 1 & 2.058963284 & 1,0000 & 0,98030 & 0,0197 \\
\hline
\end{tabular}

Berdasarkan tabel diatas diketahui bahwa nilai $S(Z)-F(Z)$ tertinggi pada data pretest sebagai angka penguji normalitas yaitu 0,5714. Sedangkan nilai penguji Liliefors dengan $\mathrm{N}=14$, dan $a=0,05$ yaitu 0,227 . Setelah dikonsultasikan ke ttabel, diketahui bahwa Lhitung $\geq$ Ltabel yaitu 0,5714 $\geq$ 0,227 . Jadi dapat disimpulkan bahwa data pretest berdistribusi tidak normal. Adapun nilai $S(Z)-F(Z)$ tertinggi pada data posttest sebagai angka penguji normalitas yaitu 0,16097 . Sedangkan nilai penguji Liliefors dengan $\mathrm{N}=14$, dan $\alpha=0,05$ yaitu 0,227 . Setelah dikonsultasikan ke Ltabel, diketahui bahwa Lhitung < Ltabel yaitu 0,16097 < 0,227 . Jadi, dapat disimpulkan bahwa data pretest berdistribusi normal.

2. Uji Homogenitas

Uji Homogenitas dilakukan untuk mengetahui apakah data sampel besifat 


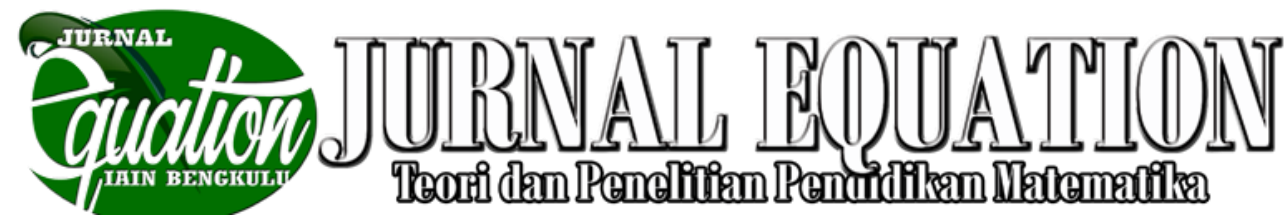

Volume 2 Nomor 1, Maret 2019, ISSN 2599-3291 (Cetak), ISSN 2614-3933 (Online)

homogen atau tidak. Uji homogenitas ini menggunakan rumus pengujian kesamaan dua varians (fisher). Berdasarkan hasil perhitungan diperoleh: Fhitung $=$ untuk $\mathrm{db} 1$ (db pembilang $)=k-1=2-1=1$, dan $\mathrm{db} 2(\mathrm{db}$ penyebut) $=n-k=14-2=12$ diperoleh Ftabel signifikan $5 \%$ adalah 4,75 . Sehingga Fhitung $<$ Ftabel $(2,43<4,75)$. Maka dapat disimpulkan bahwa varians data pretest dan data posttest bersifat homogen.

\section{Uji Hipotesis}

1. Pelaksanaan Penggunaan Math Game Kartu Remi Berhitung (Karetung) terhadap Kemampuan Operasi Hitung Siswa di SDN 8 Kabupaten Rejang Lebong Untuk mengetahui pelaksanaan penggunaan math game kartu remi berhitung (karetung) terhadap kemampuan operasi hitung siswa di SDN 8 Kabupaten Rejang Lebong, maka peneliti melakukan observasi terhadap pembelajaran pada 2 kali pertemuan dilakukan oleh 2 orang observer yaitu mahasiswa IAIN Curup Sindi Destrianti dan Saumi Ramadani dengan mengisi lembar observasi siswa. Adapun hasil observasi pada pertemuan I menunjukkan bahwa siswa masih kurang memperhatikan penjelasan guru tentang materi, siswa masih melakukan kecurangan pada permainan math games seperti mencabut kartu sebanyak dua kali, masih salah berhitung dalam bermain yaitu disebabkan karena masih kurangnya kemampuan siswa dalam berhitung sehingga menyebabkannya kesulitan dalam menurunkan kartu remi saat gilirannya memberikan kartu dan membutuhkan waktu yang cukup lama dalam bermain (lembar observasi terlampir). Adapun hasil observasi pada pertemuan II telah menunjukkan hasil yang lebih baik daripada pertemuan I dimana siswa lebih cepat bermain karena telah terbiasa dengan operasi hitung yang diberikan.

2. Penggunaan Math Game Kartu Remi Berhitung (Karetung) terhadap Kemampuan Operasi Hitung Siswa di SDN 8 Kabupaten Rejang Lebong

Untuk mengetahui pengaruh math game kartu remi berhitung (karetung) terhadap kemampuan operasi hitung siswa di SDN 8 Rejang Lebong, peneliti menggunakan teknik analisis data uji-t dua sampel. Berdasarkan hasil perhitungan didapatkan Standar Deviasi $(S D D)=5,345$ dan $S E M D=0,411$, sehingga thitung $=-48,66$ (tanda minus menunjukkan selisih derajat pengaruh sebesar 48,66).

Dalam penelitian ini, peneliti menggunakan sampel sebanyak 14 orang, maka derajat kebebasannya $\quad(d b)=\mathrm{N}-1=14-1=13$. Selanjutnya, dikonsultasikan pada nukilan tabel nilai "t" $5 \%$ sebesar 1,68. Setelah dikonsultasikan ke ttabel diketahui bahwa thitung $\geq$ ttabel yaitu $48,66>1,68$. Bedasarkan ketentuan yang berlaku untuk 


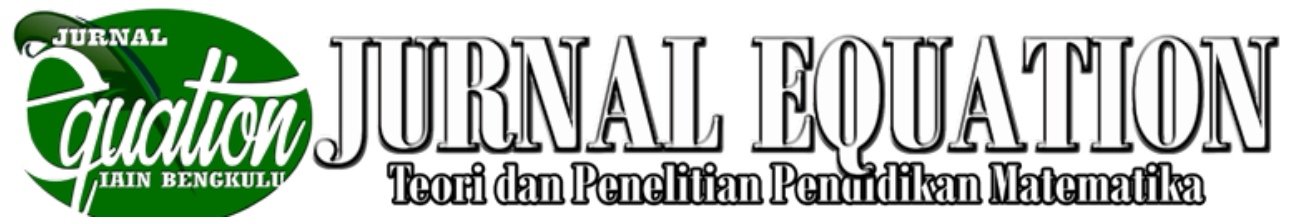

Volume 2 Nomor 1, Maret 2019, ISSN 2599-3291 (Cetak), ISSN 2614-3933 (Online)

pengujian hipotesis maka $\mathrm{Ho}$ ditolak dan $\mathrm{Ha}$ diterima. Artinya, terdapat pengaruh yang signifikan antara penggunaan Karetung terhadap kemampuan berhitung siswa SDN 8 Kabupaten Rejang Lebong.

\section{PENUTUP}

\section{Kesimpulan}

Adapun kesimpulan penelitian ini adalah sebagai berikut: Dalam pelaksanaan pembelajaran menggunakan Kartu Remi Berhitung (Karetung) pada operasi hitung terdapat pengaruh yang signifikan antara penggunaan Karetung terhadap kemampuan berhitung siswa SDN 8 Kabupaten Rejang Lebong dengan nilai thit $=48,66$ dan thitung $\geq$ ttabel yaitu $48,66 \geq 1,68$ sehingga $\mathrm{H} 0$ ditolak yang artinya $\mathrm{H} 1$ diterima. Adapun hasil observasi pada pertemuan । menunjukkan bahwa siswa masih kurang memperhatikan penjelasan guru tentang materi, siswa masih melakukan kecurangan pada permainan math games seperti mencabut kartu sebanyak dua kali, masih salah berhitung dalam bermain yaitu disebabkan karena masih kurangnya kemampuan siswa dalam berhitung sehingga menyebabkannya kesulitan dalam menurunkan kartu remi saat gilirannya memberikan kartu dan membutuhkan waktu yang cukup lama dalam bermain (lembar observasi terlampir). Adapun hasil observasi pada pertemuan II telah menunjukkan hasil yang lebih baik daripada pertemuan I dimana siswa lebih cepat bermain karena telah terbiasa dengan operasi hitung yang diberikan.

\section{Saran}

Saran dalam penelitian ini adalah Karetung ini dapat digunakan untuk tingkat SMP hingga tingkat perguruan tinggi disesuaikan dengan materi ajar yang dipelajari. Karetung ini dapat menjadi alternatif media pembelajaran matematika yang menyenangkan.

\section{DAFTAR PUSTAKA}

Aini, Z. (2017). Pengaruh Model pembelajaran Open Ended dengan Kartu Domino Terhadap Kreativitas siswa Pada Mata Pelajaran Matematika Kelas V SDIT Rabbi Radiyyah Curup. Curup: Jurusan Tarbiyah Sekolah Tinggi Agama islam Negeri Curup .

Arikunto, S. (1985). Prosedur Penelitian Suatu Pengantar praktik. jakarta: Bina Aksara.

Arikunto, S. (2002). Prosedur Penelitian. Jakarta : PT. Rineka Cipta . Arikunto, S. (2010). Manajemen Penelitian . Jakarta: Rineka Cipta .

Arikunto, S. (2013). Prosedur Penelitian Suatu Pendekatan Praktik. Jakarta : PT Rineka Cipta. 


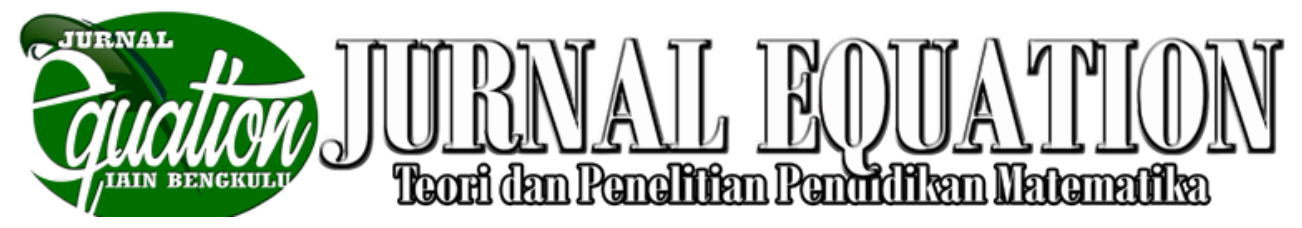

Volume 2 Nomor 1, Maret 2019, ISSN 2599-3291 (Cetak), ISSN 2614-3933 (Online)

Asep Jihad, A. H. (2008). Evalusi

Pembelajaran. Yogyakarta: Multi

pressindo . Budiyono. (2003). Metode

Penelitian Pendidikan . Surakarta:

Sebelas Maret University Press.

Darmawan, D. (2013). Metode Penelitian Kuantitatif. Bandung: PT Remaja Rosdakarya.

Daryawan Syah, d. (2007). Pengantar Statistik Pendidikan . Jakarta: Gaung Persasa Press.

Sudijono, A. (2006). Pengantar Evaluasi Pendidikan . Jakarta: PT Raja Grafindo Persada .

Sudijono, A. (2013). Pengantar Evaluasi Pendidikan. Jakarta: Rajawali Press. Sudjana, N. (2009). Penilaian Hasil Proses Belajar Mengajar . Bandung: PT Remaja Rosdakarya.

Sugiyono. (2014). Metode Penelitian Kuantitatif, Kualitatif dan $R$ \& $D$. Bandung: Alfabeta.

Syarnubi, S. (2011). Metode Penelitian Kuantitatif dan Kualitatif . Curup: Lp2 STAIN Curup.

Syarnubi, S. (2014). Metode Penelitian Suatu pendekatan Praktik. Curup : LP2 STAIN Curup. 